Annals of Warsaw University of Life Sciences - SGGW

Land Reclamation No 48 (3), 2016: 243-253

(Ann. Warsaw Univ. of Life Sci. - SGGW, Land Reclam. 48 (3), 2016)

\title{
Influence of diaphragm wall installation in overconsolidated sandy clays on in situ stress disturbance and resulting wall deformations
}

\author{
ANDRZEJ ADAM TRUTY \\ Intitute of Geotechnics, Faculty of Environmental Engineering, Cracow University of Technology
}

\begin{abstract}
Influence of diaphragm wall installation in overconsolidated sandy clays on in situ stress disturbance and resulting wall deformations. Numerical modeling of deep excavations becomes a standard practice in modern geotechnical engineering. A detailed numerical model for a given case is able to reproduce major effects of soil-structure interaction by taking into account any kind of drainage conditions, strong stiffness variation due to effective stress and strain changes, creep and cracking, when reinforced concrete is used as a structural material, but also interface effects between subsoil and structure. Calibrating soil constitutive models is one of the most difficult tasks and due to several sources of uncertainty there is no one unique set of the data that should be used in numerical predictions. Lack or incompleteness of experimental data, significant mismatch between laboratory and field tests is an another source of difficulty. Contrary to several simplified methods, that are usually limited to two dimensions, numerical models allow a full $3 \mathrm{D}$ analysis in which many simplifications can be eliminated. This paper is devoted to the problem of in situ stress disturbance caused by diaphragm wall installation in overconsolidated quaternary sandy clays and its influence on final wall deformations.
\end{abstract}

Key words: deep excavations, diaphragm walls, in situ stress disturbance

\section{INTRODUCTION}

Application of advanced soil constitutive models is one of the most important aspects when solving complex deep excavations problems. Hardening soil model with small strain overlay (Benz 2006) proved to be one of the most efficient tools in the considered class of problems. Its robustness was confirmed by several real life applications. Ability to calibrate this model using results of drained triaxial compression tests, enhanced by measurement of shear wave velocity, is the main source of its success. Proper prediction of the in situ effective stress state, initial pore water pressures, but also spatial distribution of the overconsolidation ratio $(O C R)$ has a significant influence on quality of numerical predictions. Most of deep excavations are protected with aid of diaphragm walls, anchored, or stiffened by steel pipes (for smaller distances between opposite walls) or partial slabs supported by temporary columns. Each of the wall stiffening systems has its advantages and disadvantages and it strongly influences deflections of the wall and settlements behind it. Apart from all the aforementioned factors influencing wallsubsoil interaction there is a problem of in situ stress disturbance, caused by diaphragm walls installation and foregoing aging and creep of the concrete. Careful analysis of this phenomenon, basing on previous author's studies, carried out for the Supersam deep excavation (Truty and Podleś 2010), is the aim of this paper. For its better understanding a simplified 
assumption of a homogenious subsoil is made, while a more careful attention is paid to the comprehensive description of aging concrete. This paper presents problem of in situ stress disturbance caused by wall installation. A 3D model of wall installation followed then by subsequent excavations and anchoring is described. Results of two analyses, including detailed modeling of wall installation, and a simplified one, neglecting installation effects, are presented. Basing on the achieved results final conclusions are drawn.

\section{IN SITU STRESS CONDITIONS AND ITS DISTURBANCE CAUSED BY INSTALLATION OF DIAPHRAGM WALL}

In most real life applications an assumption of lack of effective stress disturbance due to installation procedure is made, when diaphragm walls are discretized using beam (2D) or shell elements (in 3D). This is so due to the fact that most formulations for these structural elements are basing on assumption of inextensible fibers in the direction perpendicular to the axis (2D)/midsurface (3D). Moreover skipping this stage saves a significant amount of CPU time in practical computations. In the reality installation procedure consists of a simultaneous excavation of a ground panel, usually 0.6 or $0.8 \mathrm{~m}$ thick, 3 to $6 \mathrm{~m}$ wide, protected by the bentonite pressure. In the latter stage the bentonite is replaced by concrete going from the bottom of the trench to the top. The in situ effective stress coefficient $\left(K_{o}\right)$ but also the $O C R$ (in consequence stiffness and undrained shear strength), are major parameters causing different subsoil behavior and foregoing wall deflections. Part of this subject was tackled by Gorska in her PhD thesis (Gorska 2008) where a comprehensive analysis of stability of a trench filled with the bentonite was analyzed. A detailed review of the publications concerning the matter is made by $\mathrm{Ng}$ and Yan (1998). Several corresponding aspects are included in the $\mathrm{PhD}$ thesis by Montalti (2000) and paper by Gourvenec and Powrie (1999). In the paper by $\mathrm{Ng}$ and Yan (1998) a 3D arching effect is analyzed, however constitutive model they used for soil description is relatively simple. More advanced analyses were published in the paper by Schäfer et al. (2006) in which extended (to small strain regime) hypoplastic model was used for a normally consolidated subsoil, while concrete behavior was described in a very crude manner.

In this paper a detailed 3D analysis of an anchored diaphragm wall installation in the uniform layer of quaternary overconsolidated sandy clays (in Warsaw) is presented. Soil behavior is described by the Hardening Soil-small (HSs) model and its parameters were determined based on drained triaxial compression tests in the course of designing of the Supersam construction (Truty and Podleś 2010). Concrete behavior is described using the extended Lee and Fenves plastic damage model (Lee and Fenves 1998) with aging an creep following the EC2 (2008) standard (Truty 2016). To make some qualitative assessments the analyzed case study deviates from the final Supersam design and assumes an uniform subsoil while the wall panel, $6.5 \mathrm{~m}$ wide and $26 \mathrm{~m}$ long, is anchored with two rows of prestressed anchors. 
THREE-DIMENSIONAL MODEL OF DIAPHRAGM WALL

The 3D model of an anchored diaphragm wall is shown in Figure 1. Two rows of prestressed anchors, $17 \mathrm{~m}$ long (fixed anchor zone length is equal $8 \mathrm{~m}$ ), are installed at depths 5 and $11 \mathrm{~m}$, accordingly, with $1.6 \mathrm{~m}$ spacing four anchors per panel). Modeling of the wall installation stage follows, in general, the approach proposed by Schäfer and Triantafyllidis (2006). Excavation stage of each panel, lasting 0.5 day, is carried out progressively by removing elements, row by row, in 26 time steps. Simultaneously a hydrostatic bentonite pressure (unit weight of bentonite is assumed as $\gamma_{b}=$ $10.3 \mathrm{kN} / \mathrm{m}^{3}$ ) is applied in the excavated zone. This stage can easily be modeled by applying normal pressure, using fluid head option implemented in the ZSoil code (Truty et al. 2016) $(h(t)=-p(t) / \gamma$ $+y$; here minus sign is used as compressive stresses are negative), to the outer and inner element facets of all excavated elements in the panel zone, but also, to the external facets of remaining elements adjacent to the excavated panel. At end of the excavation the trench is exposed to the bentonite pressure only. Later on bentonite is replaced progressively by a fresh concrete going from the bottom to the top with $v_{c}=5 \mathrm{~m} / \mathrm{h}$ rate. Due to setting of fresh concrete, but also due to geometry of the trench, concrete pressure distribution is not hydrostatic. It is common to assume that this distribution follows so-called bilinear law (Ng and Yan 1998), in which the initial gradient cor-

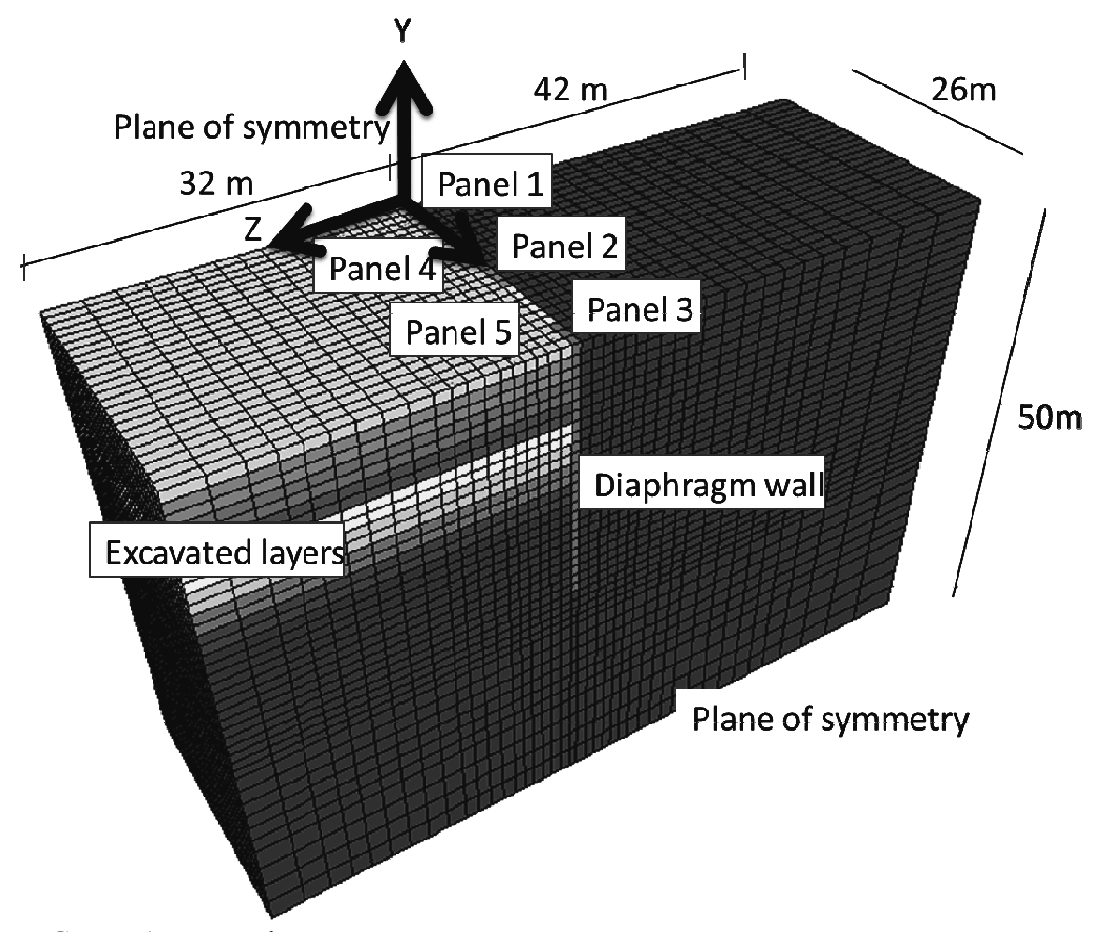

FIGURE 1. FE mesh 
responds to the unit weight of concrete $\left(\gamma_{c}\right)$, while below a certain depth, called as critical, and usually equal to the $1 / 3$ of the trench depth, pressure is significantly reduced, and follows the bentonite one. This kind of effect is well known in the community of designers of concrete formworks and worked out in several standards. Before setting time instance concrete behaves as a Bingham fluid, but then as an aging solid. In this first period (till setting time instance) evolution of fresh concrete pressure front is shown in Figure 2. To obtain such a variable in time, distribution, a linear combination of three pressure load records, using ZSoil fluid head definition, is to be used. The first record $h_{1}(t)=0$ corresponds to the bentonite pressure and can be applied in zones of panels 1, 2 and 3, from the very beginning. In panels 4 and 5 bentonite pressure is applied to the subsoil elements facets and wall (panels 1, 2 and
3) facets. Therefore, in zone of these two remaining panels, $h_{1}(t)=-26 \mathrm{~m}$ at the beginning, and then it switches to $h_{1}(t)$ $=0 \mathrm{~m}$ once wall panels 1,2 and 3 are installed. The second record $h_{2}(t)$ corresponds to the normal pressure applied in the direction opposite to the external normal of soil elements facets, in the trench, and is defined as follows

$h_{2}(t)= \begin{cases}-H & \text { for } t \leq t_{1} \\ -H\left(1-\frac{t-t_{1}}{H / v_{c}}\right) & \text { for } \quad t_{1}<t \leq t_{1}+\frac{H}{v_{c}} \\ 0 & \text { for } t>t_{1}+\frac{H}{v_{c}}\end{cases}$

The third record $h_{3}(t)$ corresponds to the normal pressure applied in the direction that coincides with the external normal of soil elements facets, in the trench, and is defined as follows

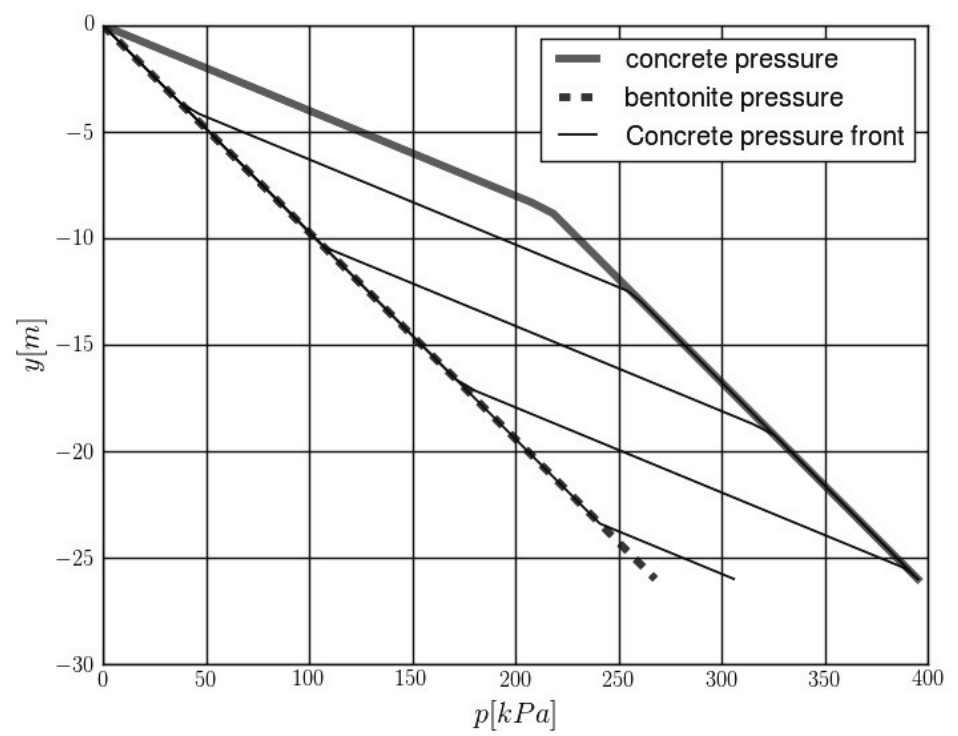

FIGURE 2. Evolution of concrete pressure front 


$$
h_{3}(t)= \begin{cases}-H & \text { for } t \leq t_{1}+\frac{h_{c}}{v_{c}} \\ -H\left(1-\frac{t-t_{1}-h_{c} / v_{c}}{\left(H-h_{c}\right) / v_{c}}\right) & \text { for } \quad t_{1}+\frac{h_{c}}{v_{c}}<t \leq t_{1}+\frac{h_{c}}{v_{c}}+\frac{H-h_{c}}{v_{c}} \\ 0 & \text { for } t>t_{1}+\frac{h_{c}}{v_{c}}+\frac{H-h_{c}}{v_{c}}\end{cases}
$$

In the pressure head record $h_{1}$ required artificial medium unit weight $\gamma=\gamma_{b}=10.3 \mathrm{kN} / \mathrm{m}^{3}$, while in records $h_{2}$ and $h_{3} \gamma=\gamma_{c}-\gamma_{b}=25-10.3=14.7 \mathrm{kN} / \mathrm{m}^{3}$. The diaphragm wall depth is denoted by (here $H=26 \mathrm{~m}$ ), critical depth is denoted by $h_{c}\left(h_{c} \approx \mathrm{H} / 3\right)$ and $t_{1}$ is some arbitrarily assumed time instance at which bentonite is progressively replaced by concrete (here $t_{1}=0.6$ day). The assumed order of installation of wall panels $(1,2$, $3,4,5)$ is shown in Figure 1. Once the instalation is finished and concrete is fully matured progressive excavation, with simultaneous dewatering, takes place till $5 \mathrm{~m}$ depth, then first row of anchors, inclined at angle $25^{\circ}$, is installed and prestressed with force $750 \mathrm{kN}$, then excavation and dewatering progresses till 11 $m$ depth at which second row of anchors is installed and prestressed with force $650 \mathrm{kN}$. The whole analysis is terminated when design excavation depth $(16 \mathrm{~m})$ is reached. To analyze the influence of wall installation and induced effective stress disturbance in subsoil the two cases are considered. In the first case (A) whole installation procedure is included while in the second one (B) concrete wall is installed without in situ stress disturbance.

In both cases a fully coupled (consolidation) and quasi-undrained analyses are run assuming that the free water table behind the wall remains at depth of $4 \mathrm{~m}$.
Subsoil consists of a uniform overconsolidated quaternary sandy clay layer for which triaxial drained and field CPTU tests were carried out (Truty and Podleś 2010). Material properties for the HSs model used to represent behavior of the analyzed soil layer are as follows $E_{0}^{r e f}=328 \mathrm{MPa}$, $v=0.2, E_{50}^{r e f}=20 \mathrm{MPa}, E_{u r}^{r e f}=70 \mathrm{MPa}$, $\mathrm{m}=0.55, \gamma_{0.7}=4 \cdot 10^{-5}, \varnothing^{\prime}=29^{\circ}, \psi^{\prime}=0^{\circ}$, $c^{\prime}=7 \mathrm{kPa}, O C R=7.5, K_{o}^{\text {insitu }}=1.4$, $k=10^{-8} \mathrm{~m} / \mathrm{s}$. Contrary to the author's publication (Truty and Podleś 2010) a reduced value of the reference small strain moduli $E_{0}^{r e f}$ is used due to more conservative stiffness estimation derived from the measurement of shear wave velocity in the triaxial apparatus. The $O C R$ and in situ $K_{O}$ coefficients were derived from the CPTU test (at depth $17 \mathrm{~m}$ an average value of $q_{c} \approx 7 \mathrm{MPa}$ and $f_{s} \approx 330 \mathrm{kPa}$ ). The aforementioned value of the $O C R$ was derived using lower bound estimate $O C R \approx 0.2 Q_{t}$ while $K_{o}^{\text {insitu }} \approx\left(1-\sin \phi^{\prime}\right) O C R^{0.5}$. These values match relatively well the estimates given by Kaczyński et al. (2008). Stabilized (due to quasi-undrained conditions during installation stage and equal order interpolation of displacements and pore water pressures) eight-node brick BBAR 
elements were used to discretize subsoil (Truty and Zimmermann 2006).

In all cases diaphragm walls are discretized with aid of Q4 MITC shell elements possessing typical brick B8 geometry. For proper representation of concrete behavior a plastic damage model was used taking into account aging and creep, compatible with the Eurocode 2 standard (Truty and Zimmermann 2015, Truty 2016, Truty et al. 2016). This description is definitely more appropriate than the one used by Schäfer and Triantafyllidis (2006) who arbitrarily reduced value of $E$ modulus in the linear elastic model of the matured concrete, in the wall, to 2,000 $\mathrm{MPa}$. Major reinforcement $\left(60 \mathrm{~cm}^{2} / \mathrm{m}\right)$ is put on both sides of the cross section, in the vertical direction, minor one is $15 \mathrm{~cm}^{2} / \mathrm{m}$. Material properties for fully matured concrete are as follows: $E_{28}=30,000 \mathrm{MPa}, v=0.2$, $\gamma=25 \mathrm{kN} / \mathrm{m}^{3}, f_{c}=25 \mathrm{MPa}, f_{c o} / f_{c}=0.4, f_{c b o} /$ $\mid f_{c}=1.16, \tilde{D}_{c}=0.5$ at $\tilde{\sigma}_{c} / f_{c}=1.0, G_{c}=$ $=17.55 \cdot 10^{-3} \mathrm{MN} / \mathrm{m}, f_{t}=2 \mathrm{MPa}, \tilde{D}_{t}=0.5$ at $\tilde{\sigma}_{t} / f_{t}=0.5, G_{t}=0.135 \cdot 10^{-3} \mathrm{MN} / \mathrm{m}$, $s_{o}=0.2, \alpha_{p}=0.2, \alpha_{d}=1.0$. Notion of these parameters is given in the original paper by Lee and Fenves (1998) and atricle of Truty et al. (2016). Additional creep parameters of the model derived from the EC2 standard are $\emptyset_{o} \beta\left(f_{c m}\right) / E_{28}=$ $=9 \cdot 10^{-5} \mathrm{MPa}, \beta_{H}=1,500$ days, $s=0.38$. To model strong displacement discontinuity a frictional contact interface is assumed between wall and subsoil (friction angle in the interface is $\varnothing_{i}=20^{\circ}$ ). In order to reduce number of nodes denser mesh is used in zone adjacent to the wall while coarser one elsewhere. Connection of these two meshes using so-called mesh tying method preserves a perfect match between kinematical and pressure degrees of freedom in this artificial interface (Puso 2003).

\section{ANALYSIS OF RESULTS}

In order to assess stress disturbance due to wall installation the horizontal effective and total stress diagrams ( $\sigma_{z}$ component) at two different depths $4.5 \mathrm{~m}$ and $20.5 \mathrm{~m}$, in soil elements adjacent to the wall, for two types of drainage conditions, are analyzed. Distribution of $\sigma_{z}$, at depth $4.5 \mathrm{~m}$ for the undrained conditions are shown in Figure 3 and Figure 4 while for partial drainage in Figure 5 and Figure 6, respectively. The corresponding results at depth $20.5 \mathrm{~m}$ are shown in Figure 7 and Figure 8 for undrained conditions and in Figure 9 and Figure 10 for partial drainage. In all cases stress diagrams are smoothed to cancel fluctuations near panel vertical edges. On may observe that averaged total horizontal stresses after wall installation are always smaller that those corresponding to the in situ state. As far as effective $\sigma_{z}^{\prime}$ stresses are concerned one may observe that at depth $4.5 \mathrm{~m}$ differences between the state just after the installation of the wall and in situ are negligible. At depth $20.5 \mathrm{~m}$ the undrained condition yields averaged effective $\sigma_{z}^{\prime}$ stresses larger than those corresponding to the in situ state while in the case of partial drainage situation is the opposite. The resulting wall deflections in all four analyzed cases are shown in Figure 11. It is well visible that resulting deformations are much more sensitive to the drainage conditions rather than to the detailed modeling of installation effects. The latter ones generate 


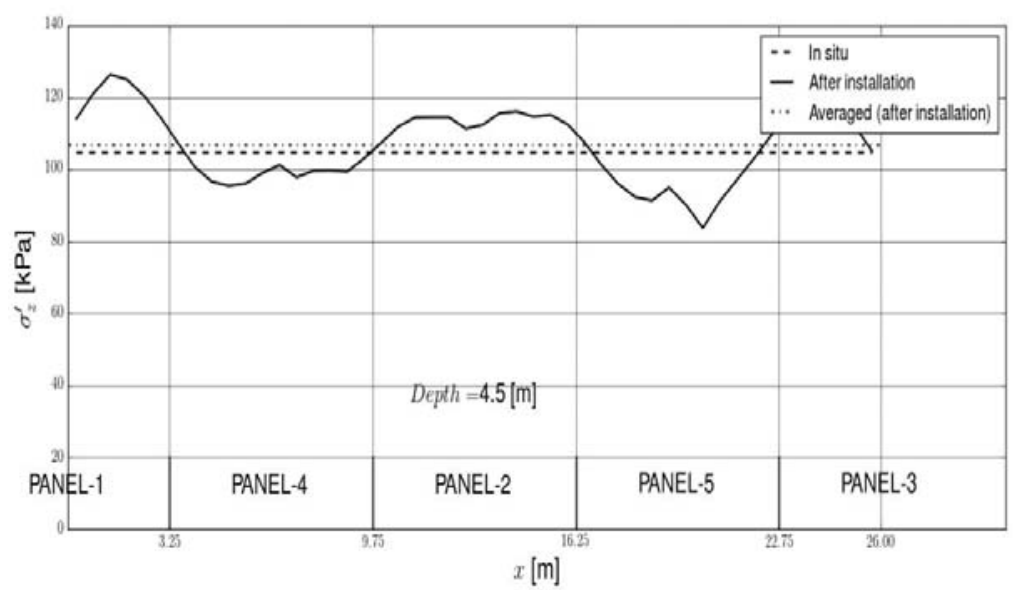

FIGURE 3. Distribution of effective stresses $\sigma_{z}^{\prime}$ in the first row of elements adjacent to the diaphragm wall at depth $4.5 \mathrm{~m}$ (quasi-undrained solution)

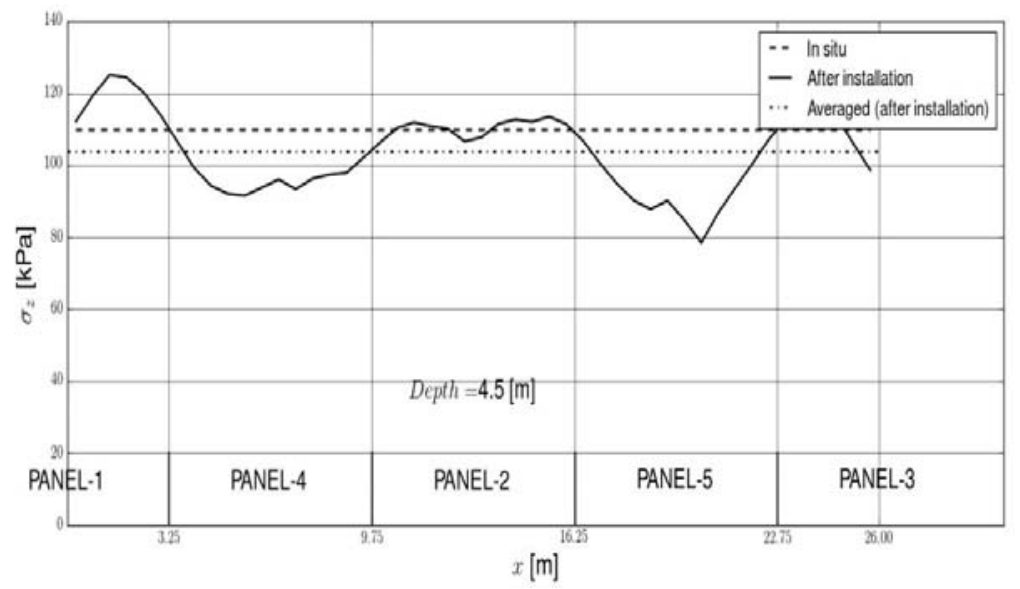

FIGURE 4. Distribution of total stresses $\sigma_{z}$ in the first row of elements adjacent to the diaphragm wall at depth $4.5 \mathrm{~m}$ (quasi-undrained solution)

some differences in terms of deflections at larger depths. This can be explained by the fact that in shallow subsoil layers averaged minor effective stresses do not deviate too much from the in situ state while at larger depths these differences are much larger. It has to be emphasized that analyzed models, at excavation and anchoring stages, do not represent real $3 \mathrm{D}$ effects due to assumed symmetries.
Hence response of the system at this stage is closer to the plane strain model. This is usually observed by means of excessive horizontal wall tip movement that is significantly reduced when true 3D models are used. However, qualitative assessment is still possible. It has to be mentioned that to avoid excessive pore water suctions zero dilatancy angle was assumed (HSs model yields 


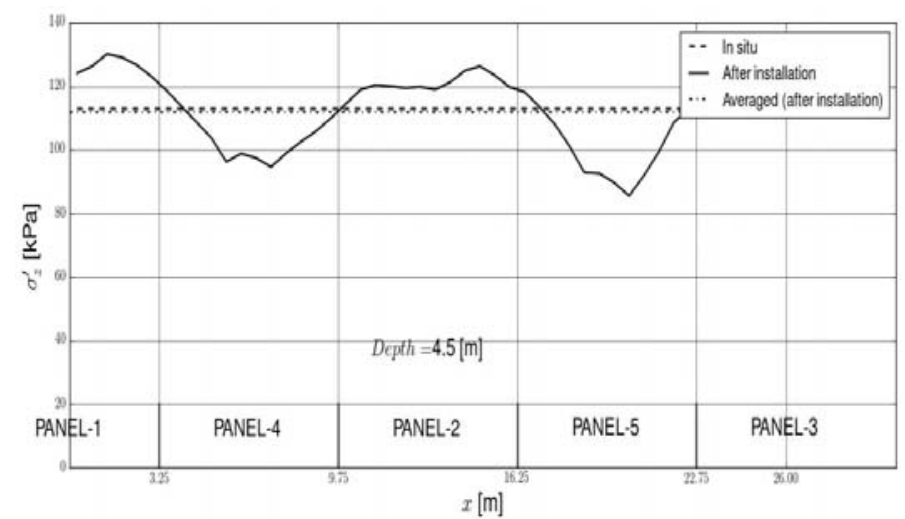

FIGURE 5. Distribution of effective stresses $\sigma_{z}^{\prime}$ in the first row of elements adjacent to the diaphragm wall at depth $4.5 \mathrm{~m}$ (partial drainage conditions)

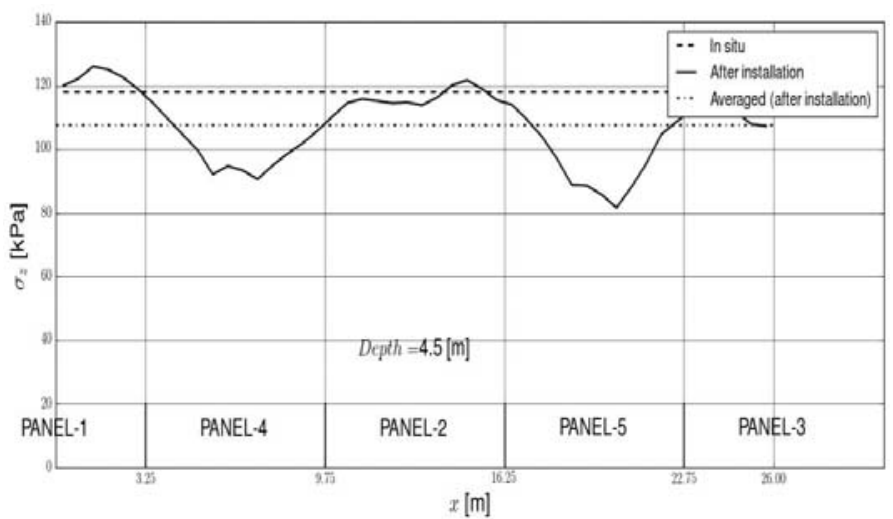

FIGURE 6. Distribution of total stresses $\sigma_{z}$ in the first row of elements adjacent to the diaphragm wall at depth $4.5 \mathrm{~m}$ (partial drainage conditions)

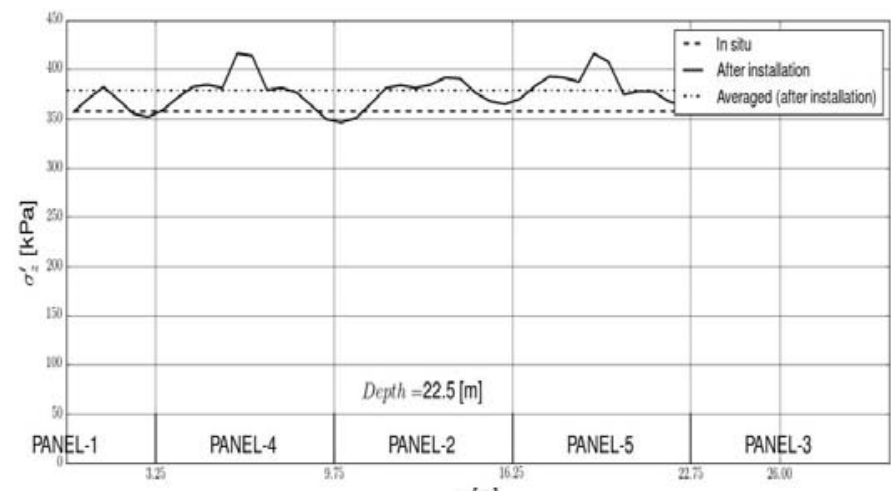

$x$ [m]

FIGURE 7. Distribution of effective stresses $\sigma_{z}^{\prime}$ in the first row of elements adjacent to the diaphragm wall at depth $20.5 \mathrm{~m}$ (quasi-undrained solution) 


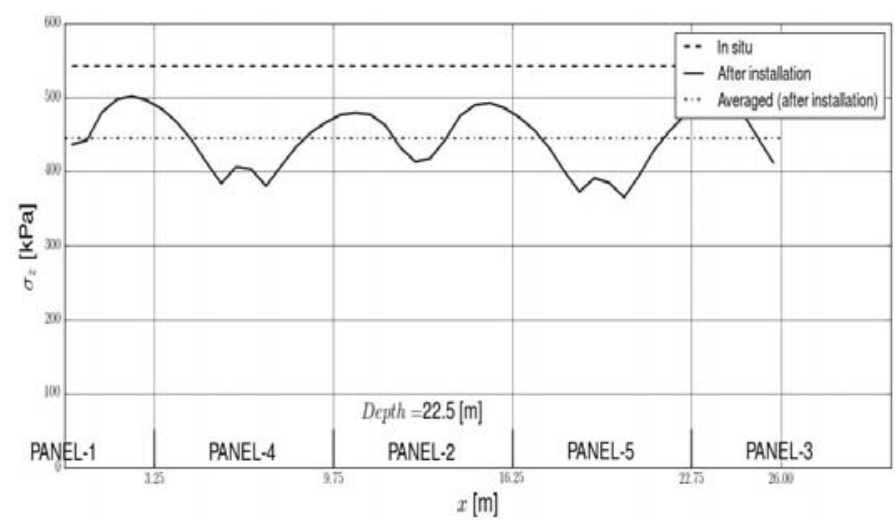

FIGURE 8. Distribution of total stresses $\sigma_{z}$ in the first row of elements adjacent to the diaphragm wall at depth $20.5 \mathrm{~m}$ (quasi-undrained solution)

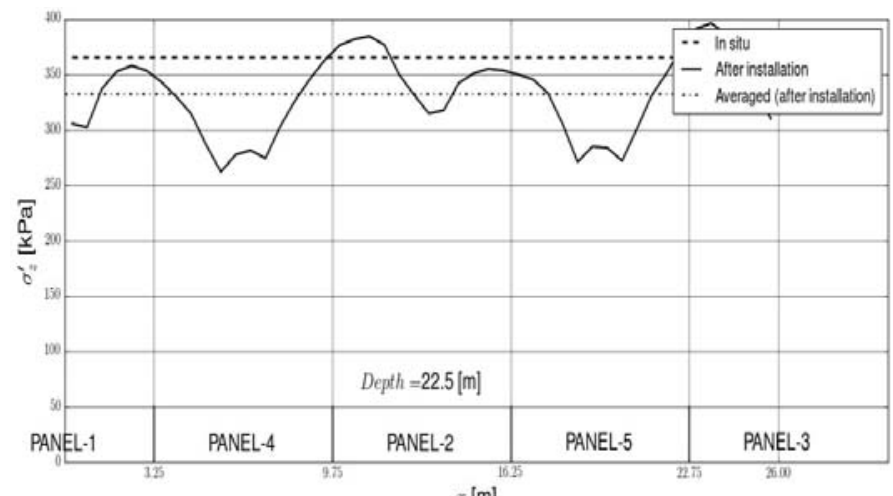

$x[\mathrm{~m}]$

FIGURE 9. Distribution of effective stresses $\sigma_{z}^{\prime}$ in the first row of elements adjacent to the diaphragm wall at depth $20.5 \mathrm{~m}$ (partial drainage conditions)

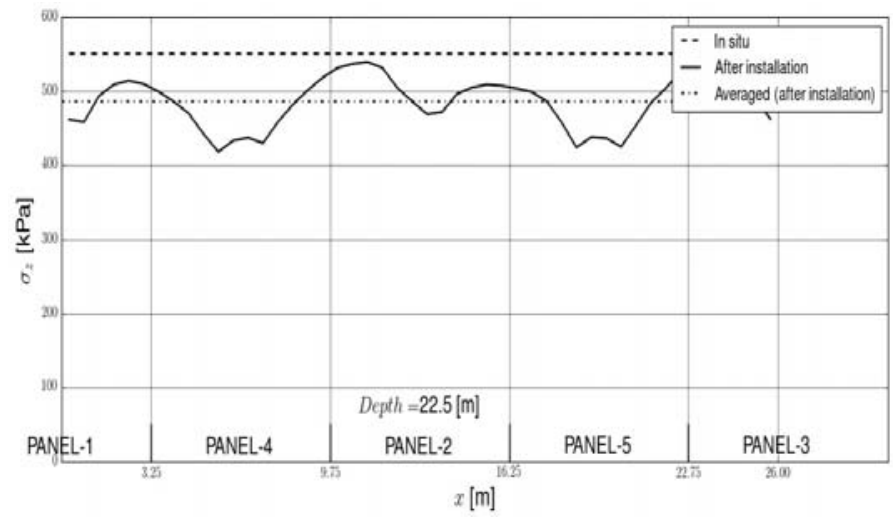

FIGURE 10. Distribution of total stresses $\sigma_{z}$ in the first row of elements adjacent to the diaphragm wall at depth $20.5 \mathrm{~m}$ (partial drainage conditions) 


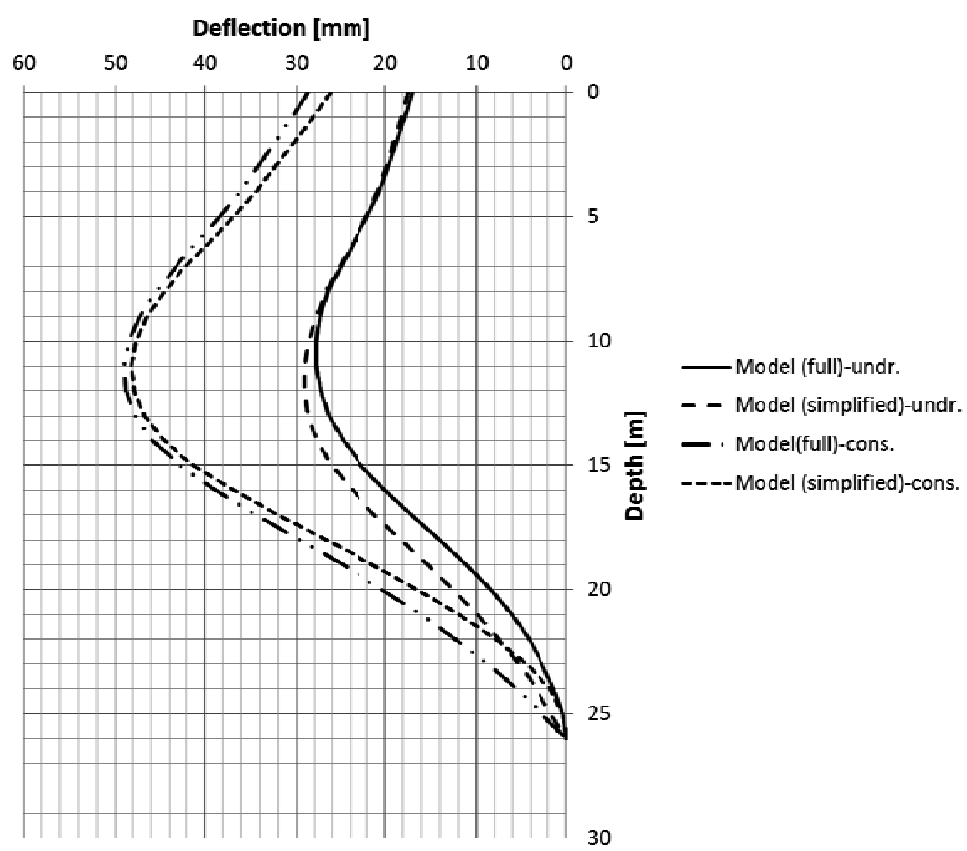

FIGURE 11. Diaphragm wall deflections at end of excavation (140 days after wall installation) for two different drainage conditions and two situations in which installation effects is neglected or taken into account

unlimited undrained shear strength for nonzero dilatancy angles (Truty and Obrzud 2015). This conservative assumption will always lead to overestimation of deformations.

\section{CONCLUSIONS}

The detailed 3D analysis of an anchored diaphragm wall installation, in overconsolidated quaternary sandy clays, was presented. For proper assessment of the diaphragm wall deflections advanced constitutive models, for both subsoil and concrete, were used. Two numerical models, one in which effect of installation was neglected and the next one in which progressive wall installation was included, under two different drain- age conditions, were considered. It was shown that the final effective stress disturbance caused by wall installation does not influence significantly its deflections. This result must be verified in the future by using a modified version of the HSs model in which $p^{\prime}$-stiffness dependency, rather than the $\sigma_{3}^{\prime}$ one, is used.

\section{REFERENCES}

BENZ T. 2006: Small-strain stiffness of soils and its numerical consequences. $\mathrm{PhD}$ thesis. University of Stuttgart, Stuttgart.

GORSKA K. 2008: Stability of a vertical trench in subsoil $\mathrm{PhD}$ thesis. Instytut Geotechniki i Hydrotechniki, Politechnika Wrocławska, Wrocław (in Polish).

GOURVENEC S., POWRIE W., 1999: Three-dimensional finite-element analy- 
sis of diaphragm wall installation. Gèotechnique 49 (6), 801-823.

KACZYŃSKI R. 2008: Formation of engineering properties of soils during geological history. Geologija 124, 4-10.

LEE J., FENVES G. 1998: Plastic-damage model for cyclic loading of concrete structures. J. Eng. Mech. 124, 892-900.

MONTALTI L. 2000: 3D modelling of bored pile installation effects and long term monitoring of a propped retaining wall. $\mathrm{PhD}$ thesis. Univeristy of Southampton, Faculty of Engineering, Science and Mathematics School of Civil Engineering and the Environment.

NG C., YAN R. 1998: Stress transfer and mechanisms around a diaphragm wall panel. J. Geotech. and Geoenvir. Eng. 50, 638-648.

PUSO M. 2003: A 3D mortar method for solid mechanics. Inter. J. Num. Meth. Eng. 59, 315-336.

SCHÄFER R., TRIANTAFYLLIDIS T. 2006: The influence of the construction process on the deformation behaviour of diaphragm walls in soft clayey ground. Inter. J. Num. Anal. Meth. Geomech. 30, 563-576.

TRUTY A. 2016: Elastic-plastic damage model for concrete. Technical Report. ZACE Services (www.zsoil.com).

TRUTY A., OBRZUD R. 2015: Improved formulation of the Hardening Soil model in the context of modeling the undrained behavior of cohesive soils. Studia Geotechnica et Mechanica 37 (2), 61-68.

TRUTY A., PODLEŚ K. 2010: Application of Hardening Soil-small model for analysis of soil-structure interaction problems. Tech. Tran. 1, 117-134 (in Polish).
TRUTY A., ZIMMERMANN T. 2015: Modified Lee-Fenves plastic-damage model for concrete. Numerics in geotechnics and structures. Elmepress, Lausanne, Switzerland.

TRUTY A., ZIMMERMANN T., PODLEŚ K., OBRZUD R. 2016: ZSoil.PC. Data preparation (www.zsoil.com).

TRUTY A., ZIMMERMANN T. 2006: Stabilized mixed finite element formulations for materially nonlinear partially saturated two-phase media. Comp. Meth. App. Mech. Eng. 195, 1517-1546.

Streszczenie: Wplyw procesu instalacji ścian szczelinowych na zaburzenie poczatkowego stanu naprężen $w$ prekonsolidowanych glinach piaszczystych oraz deformacje ściany. W pracy przedstawiono problematykę zaburzenia początkowego stanu naprężeń wywołanego procesem instalacji ściany szczelinowej $\mathrm{w}$ podłożu zbudowanym $\mathrm{z}$ prekonsolidowanych czwartorzędowych glin piaszczystych. Przeprowadzono zaawansowaną analizę numeryczną uwzględniającą silną zmianę sztywności podłoża w zakresie małych odkształceń oraz efekty dojrzewania, pełzania i zarysowania żelbetowej konstrukcji ściany. Pokazano dodatkowo wpływ procesu instalacji na wynikowe deformacje ściany szczelinowej.

MS received June 2016
Author's address:
Andrzej Adam Truty
Instytut Geotechniki
Wydział Inżynierii Środowiska
Politechnika Krakowska
31-155 Kraków, ul. Warszawska 24
Poland
e-mail: andrzej.truty@gmail.com 